\title{
PERSENTASE ORGAN DALAM ITIK CIHATEUP YANG DIBERI RANSUM MENGANDUNG KOMBINASI TEPUNG KULIT BUAH MANGGIS DAN TEPUNG KUNYIT
}

\section{THE INTERNAL ORGAN PERCENTAGE OF CIHATEUP DUCK THAT GIVEN RATION CONTAINING COMBINATION OF MANGOSTEEN PEEL AND TURMERIC FLOUR}

\author{
Andri Kusmayadi ${ }^{*}$, Caribu Hadi Prayitno ${ }^{2}$, Novia Rahayu ${ }^{1}$ \\ ${ }^{1}$ Department of Animal Science, Faculty of Agriculture, Universitas Perjuangan, Pembela Tanah Air \\ Street, Tawang, Tasikmalaya - 46115, Indonesia. \\ ${ }^{2}$ Department of Feed Science, Faculty of Animal Science, Universitas Jenderal Soedirman, Dr. \\ Soeparno, North Purwokerto, Banyumas - 53122, Indonesia. \\ ${ }^{a}$ Korespondensi : andrikusmayadil@gmail.com
}

(Diterima oleh Dewan Redaksi: 16 Maret 2019)

(Disetujui oleh Dewan Redaksi: 18 April 2019)

\begin{abstract}
This study aims to assess the appropriate level of the combination of mangosteen peel and turmeric flour in the ration to the percentage of internal organs in the Cihateup duck. The study used 84 ducks grouped randomly into 7 groups of feed treatment as follows: basal ration only as a negative control (R0); $0.5 \% \mathrm{MF}+0.5 \% \mathrm{TF}$ (R1); $1.0 \% \mathrm{MF}+1.0 \% \mathrm{TF}$ (R2); $1.5 \% \mathrm{MF}+1.5 \% \mathrm{TF}$ (R3); $2.0 \% \mathrm{MF}+2.0 \%$ TF (R4); $2.5 \% \mathrm{MF}+2.5 \% \mathrm{TF}$ (R5) and positive controls containing synthetic antibiotic (R6). The study was designed using a completely randomized design, the data were analyzed for variance and if there were significant differences it would be continued using the DMRT method. The results showed that the level of combination of mangosteen peel and turmeric flour had a significant effect $(\mathrm{P}<0,05)$ on the percentage of internal organs: liver, gizzard, lymph, and intestinal length while in other internal organs (proventriculus, pancreas, intestinal weight, kidney, and heart), there is no significant effect $(P>0,05)$. The use of MF and TF in duck rations look at a tendency to increase the percentage of internal organs as doses increase. However, the use of high doses should be limited as it can cause toxic accumulation in the digestive organs so that it can reduce the characteristics of the digestive organs.

Keywords: feed additive, Cihateup duck, internal organ percentage, mangosteen peel flour, turmeric flour

ABSTRAK

Penelitian ini bertujuan untuk mengkaji level yang tepat pemberian kombinasi tepung kulit buah manggis dan tepung kunyit pada ransum terhadap persentase organ dalam itik Cihateup. Penelitian menggunakan 84 ekor DOD itik Cihateup yang dikelompokkan secara acak kedalam 7 kelompok perlakuan pakan sebagai berikut: ransum basal saja sebagai kontrol negatif $\left(\mathrm{R}_{0}\right) ; 0,5 \% \mathrm{TKBM}+0,5 \%$ TK (R1); 1,0\% TKBM+ 1,0\% TK (R2); 1,5\% TKBM+ 1,5\% TK (R3); 2,0\% TKBM+ 2,0\% TK (R4); 2,5\% TKBM $+2,5 \%$ TK (R5) dan kontrol positif yang mengandung antibiotik sintetis $\left(\mathrm{R}_{6}\right)$. Penelitian dirancang menggunakan rancangan acak lengkap, data dianalisis variansi dan apabila terdapat perbedaan yang nyata akan dilanjutkan menggunakan metode DMRT. Hasil penelitian menunjukkan bahwa level kombinasi tepung kulit buah manggis dan tepung kunyit berpengaruh nyata $(\mathrm{P}<0,05)$ terhadap persentase organ dalam: hati, gizzard, limfa dan panjang usus sementara pada organ dalam lainnya (proventrikulus, pancreas, bobot usus, ginjal dan jantung) tidak berpengaruh nyata $(\mathrm{P}>0,05)$. Penggunaan TKBM dan TK pada ransum itik Cihateup memiliki kecenderungan semakin meningkatkan persentase organ dalam seiring bertambahnya dosis. Meskipun demikian, penggunaan pada dosis tinggi perlu dibatasi karena dapat mengakibatkan terjadinya akumulasi toksik pada organ pencernaan sehingga dapat mengurangi karakteristik organ pencernaan.
\end{abstract}

Kata kunci: imbuhan pakan, itik Cihateup, persentase organ dalam, tepung kulit buah manggis, tepung kunyit. 
A Kusmayadi, CH Prayitno, N Rahayu. 2019. Persentase Organ Dalam Itik Cihateup Yang Diberi Ransum Mengandung Kombinasi Tepung Kulit Buah Manggis Dan Tepung Kunyit. Jurnal Peternakan Nusantara 5(1): 1-12 .

\section{PENDAHULUAN}

Pengembangan itik Cihateup masih perlu ditingkatkan mengingat potensinya sebagai penghasil pangan hewani bagi masyarakat sangat dibutuhkan dalam kehidupan seharihari. Namun demikian, masih terdapat beberapa masalah seperti mudah stress dan terserang berbagai penyakit sehingga akan tercermin pada karakteristik organ dalam yang dihasilkannya. Selama ini peternak masih ketergantungan dengan antibiotik sintetis untuk memacu pertumbuhan ternak agar tingkat stress dan penyakit dapat teratasi. Padahal sudah banyak hasil penelitian yang melaporkan tentang dampak negatif penggunaan antibiotik sintetis baik pada ternak masih hidup, pangan yang akan dihasilkan maupun manusia sebagai konsumen produk ternak. Oleh karena itu, perlu dicari sumber alternatif antibiotik alami yang aman digunakan seperti pemanfaatan fitobiotik yang berasal dari tanaman herbal.

Kulit buah manggis dan kunyit berpotensi dijadikan sebagai feed additive mengingat kandungan bioaktifnya yang sudah terbukti efektif dalam memacu pertumbuhan ternak. Kedua bahan herbal ini ketersediaannya melimpah, harganya murah dan memiliki manfaat yang sudah terbukti khasiatnya. Weecharangsan et al. (2016) melaporkan bahwa ekstrak kulit buah manggis mempunyai potensi sebagai penangkap radikal bebas sehingga dapat menurunkan tingkat stres, meningkatkan kekebalan tubuh serta memperbaiki performan, profil lipid darah dan lemak abdominal itik (Kusmayadi et al., 2019a). Hal ini disebabkan oleh kulit buah manggis mengandung senyawa bioaktif xanton yang memiliki manfaat sebagai antioksidan (Kusmayadi et al., 2019b), antikanker, antiinflamasi, dan antibiotik (Moongkarndi et al., 2014). Disamping itu, kunyit banyak dilaporkan memiliki aktifitas antibakteri
(Moghadamtousi, et. al., 2014), antioksidan dan antiinflamasi (Akram, et. al., 2014) serta hepatoprotektif (Ayoub, et. al., 2011). Selain itu, kunyit merupakan senyawa antioksidan yang mampu melindungi tubuh unggas terhadap stress dengan menurunkan produksi radikal bebas pada ternak yang diuji tantang dengan aflatoksin B1 (Ahmadi, 2010).

Penelitian lain melaporkan bahwa baik kulit buah manggis maupun kunyit berperan dalam meningkatkan efektivitas sistem pencernaan dengan menyeimbangkan populasi mikroflora usus melalui sifat antimikroba yang dimilikinya (Erhan et al., 2012). Kedua bahan herbal ini (tepung kulit buah manggis dan tepung kunyit) belum pernah diujicobakan secara bersamaan dan diduga akan berfungsi lebih signifikan hasilnya. Pada penelitian ini akan diuji level perlakuan kombinasi tepung kulit buah manggis dan tepung kunyit dalam ransum terhadap persentase organ dalam itik Cihateup.

\section{MATERI DAN METODE}

\section{Materi}

Kulit buah manggis, kunyit, DOD itik Cihateup, ransum basal itik pedaging, air minum dan vitamin. Mesin giling, blender, kandang, timbangan, oven, tempat pakan, tempat air minum, plastik, pensil, label, termometer, tag dan kertas tisu.

\section{Perlakuan}

Perlakuan yang diterapkan yaitu pemberian 7 jenis formulasi ransum yang berbeda yaitu:

$\mathrm{R} 0=$ Ransum basal (kontrol negative)

$\mathrm{R} 1=\mathrm{RB}+0,5 \%$ tepung kulit buah manggis + $0,5 \%$ tepung kunyit

$\mathrm{R} 2=\mathrm{RB}+1,0 \%$ tepung kulit buah manggis + $1,0 \%$ tepung kunyit

$\mathrm{R} 3=\mathrm{RB}+1,5 \%$ tepung kulit buah manggis + $1,5 \%$ tepung kunyit 
$\mathrm{R} 4=\mathrm{RB}+2,0 \%$ tepung kulit buah manggis + $2,0 \%$ tepung kunyit

$\mathrm{R} 5=\mathrm{RB}+2,5 \%$ tepung kulit buah manggis + $2,5 \%$ tepung kunyit

$\mathrm{R} 6=\mathrm{RB}+$ basitrasin $50 \mathrm{ppm}$ (kontrol positif)

\section{Rancangan Percobaan}

Penelitian dilakukan secara eksperimen menggunakan 84 ekor DOD itik Cihateup dengan menggunakan Rancangan Acak Lengkap (RAL) yang terdiri atas 7 perlakuan dan 4 ulangan.

\section{Peubah yang Diamati}

Pengukuran bobot organ dalam diperoleh dari pembagian antara bobot organ dengan bobot hidup broiler dikalikan dengan 100\% (setelah disisihkan lemak yang melekat) (Auza, 2010).

$\%$ berat organ dalam $=$

$\frac{\text { Bobot organ dalam itik }}{\text { Bobot potong itik }} \times 100 \%$

\section{Analisis Data}

Data yang dperoleh diolah dengan menggunakan sidik ragam sesuai Rancangan Acak Lengkap (RAL) pola searah. Jika ada perbedaan nyata dilanjutkan dengan uji DMRT menggunakan metode SPSS-21.

\section{Prosedur Pelaksanaan}

Perlakuan pemberian tepung kulit buah manggis dan tepung kunyit dilakukan melalui pencampuran dengan ransum pakan yang dimulai pada minggu kedua hingga akhir periode pemeliharaan yaitu pada umur 56 hari.

\section{HASIL DAN PEMBAHASAN}

Persentase organ dalam yang diukur dalam penelitian ini adalah persentase proventrikulus, pancreas, hati, gizzard, limfa, bobot usus halus, panjang usus halus, ginjal, dan jantung. Rataan hasil penelitian ini tersaji pada Tabel 1 dan Tabel 2 .

\section{Proventrikulus}

Data persentase proventrikulus sebagaimana tersaji pada Tabel 1. menunjukkan bahwa perlakuan pakan tidak berpengaruh secara signifikan $(\mathrm{P}>0,05)$ terhadap persentase bobot proventrikulus. Rataan persentase bobot proventrikulus hasil penelitian secara berturutturut adalah adalah berkisar antara 0,41 $0,60 \%$. Hal ini masih dalam kisaran normal dan sesuai dengan penelitian sebelumnya yang melaporkan bahwa persentase bobot proventrikulus unggas berkisar antara 0,47 $0,57 \%$ dari bobot potong. Peneliti lain melaporkan rataan persentase bobot proventrikulus sebesar 0,39\% (Awad et al., 2009), 0,45\% (Djunaidi et al., 2009) dan 0,45\%-0,56\% (Elfiandra, 2007; Siregar, 2011) dari bobot potong. Hasil penelitian ini membuktikan bahwa perlakuan pakan yang mengandung kombinasi dua bahan herbal, TKBM dan TK, tidak mempengaruhi fungsi dan kinerja dari proventrikulus. Rataan persentase bobot proventrikulus ayam broiler hasil penelitian tidak berbeda nyata. Hal ini dikarenakan kandungan protein pakan yang diberikan pada semua perlakuan sama. Kondisi ini menyebabkan intake protein relatif sama, sehingga kerja proventrikulus dalam mensekresikan pepsin untuk pencernaan protein tidak berbeda.

Perlakuan pakan yang mengandung kombinasi TKBM dan TK pada level 2,5\% menghasilkan persentase bobot proventrikulus yang lebih tinggi dibandingkan perlakuan lainnya. Hal ini dikarenakan TKBM dan TK pada level tersebut mengandung xanton dan kurkumin dalam pakannya pada dosis yang optimal dalam membantu mensekresikan enzim pada pepsin pada proventrikulus. Elfiandra (2007) dalam Siregar (2011) menjelaskan bahwa kerja proventrikulus mensekresikan enzim pepsin akan berdampak pada bobot proventrikulus. Proventrikulus mensekresikan enzim pepsin dan merupakan awal dari pencernaan protein agar dapat dipecah menjadi komponen sederhana. Pepsin bekerja dengan menghidrolisis ikatan-ikatan peptida protein menjadi peptida yang lebih kecil. Asam hidroklorida juga menyebabkan protein globular mengalami denaturasi sehingga ikatan 
peptida lebih terbuka terhadap hidrolisis enzimatik (Lehninger, 1982; Siregar, 2011).

\section{Pankreas}

Berdasarkan analisis statistika pada Tabel 1. menunjukkan bahwa perlakuan pakan tidak berpengaruh secara signifikan $(\mathrm{P}>0,05)$ terhadap persentase berat pankreas. Rataan hasil penelitian perlakuan pakan secara berturut-turut adalah sebagai berikut 0,25, $0,13,0,35,0,28,0,37,0,45$, dan 0,33 . Hal ini sesuai dengan laporan (Sturkie, 2000; Simamora, 2011) bahwa persentase normal berat pancreas unggas sekitar 0,25-0,40\% dari bobot hidup atau sekitar 2,5 - 4,0 g. Berdasarkan data hasil penelitian dilaporkan bahwa perlakuan pakan yang mengandung kombinasi TKBM dan TK memiliki nilai persentase yang lebih tinggi. Hal ini membuktikan bahwa penambahan kombinasi TKBM dan TK dalam ransum mempengaruhi kinerja atau fungsi pangkreas itik Cihateup. Peningkatan persentase berat pancreas pada perlakuan kombinasi TKBM dan TK dapat disebabkan oleh adanya kandungan tannin dan saponin yang dimiliki oleh kulit buah manggis dan kunyit yang diduga menjadi penyebab terjadinya pembesaran pancreas (Darmawan, 2008; Faishal et al., 2013).

Persentase bobot pancreas terbaik pada hasil penelitian ditemukan pada perlakuan R5 yang mengandung kombinasi TKBM dan TK sebesar 2,5\%. Perlakuan ini memiliki dosis tertinggi dibandingkan perlakuan lainnya dan pada dosis $2,5 \%$ ini merupakan dosis optimal dalam membantu kinerja pancreas dalam menghasilkan enzim pencernaan pakan. Peningkatan bobot pancreas merupakan salah satu bentuk adaptasi untuk mencukupi kebutuhan enzim pencernaan yang meningkat dimana fungsi pankreas adalah menghasilkan enzim-enzim lipolitik, amilolitik dan proteolitik (Pilliang dan Djojosoebagio, 2006; Faishal et al., 2013). Pankreas unggas berfungsi untuk mensekresikan getah pankreas yang berfungsi dalam pencernaan pati, lemak, dan protein oleh enzim yang dimilikinya. Selain dengan mensekresikan getah pancreas, pankreas juga berfungsi untuk mensekresikan hormon insulin. Pankreas unggas memiliki dua fungsi utama yang semuanya berhubungan dengan penggunaan energi ransum, yaitu eksokrin dan endokrin. Pankreas eksokrin berfungsi untuk mensuplai enzim yang mencerna karbohidrat, protein, dan lemak ke dalam usus halus dengan mensekresikan enzim amilase, tripsin, dan lipase yang dibawa ke duodenum untuk menerima karbohidrat, protein, dan lemak. Pangkreas terletak di antara lipatan duodenum yang merupakan bagian dari usus halus (Rahayu et al., 2011; Aqsa et al., 2016). Adapun pankreas endokrin berfungsi dalam menggunakan dan mengatur nutrien berupa energi untuk diserap dalam tubuh untuk proses pencernaan. Faktor yang mempengaruhi persentase berat pankreas yaitu faktor genetik, tingkah laku dan lingkungan (Yuwanta, 2004; Aqsa et al., 2016).

Tabel 1. Karakteristik Organ Dalam Itik Cihateup Hasil Penelitian

\begin{tabular}{cccccc}
\hline Perlakuan & $\begin{array}{c}\text { Proventrikulus } \\
(\%)\end{array}$ & $\begin{array}{c}\text { Pankreas } \\
(\%)\end{array}$ & $\begin{array}{c}\text { Hati } \\
(\%)\end{array}$ & $\begin{array}{c}\text { Gizzard } \\
(\%)\end{array}$ & $\begin{array}{c}\text { Limfa } \\
(\%)\end{array}$ \\
\hline $\mathrm{R}_{0}$ & $0,44 \pm 0,18$ & $0,25 \pm 0,17$ & $1,88^{\mathrm{a}} \pm 0,53$ & $2,18^{\mathrm{a}} \pm 0,23$ & $0,22^{\mathrm{a}} \pm 0,07$ \\
$\mathrm{R}_{1}$ & $0,41 \pm 0,07$ & $0,13 \pm 0,09$ & $1,97^{\mathrm{a}} \pm 0,55$ & $1,90^{\mathrm{a}} \pm 0,76$ & $0,22^{\mathrm{a}} \pm 0,05$ \\
$\mathrm{R}_{2}$ & $0,49 \pm 0,05$ & $0,35 \pm 0,14$ & $2,74^{\mathrm{b}} \pm 0,63$ & $2,56^{\mathrm{ab}} \pm 1,46$ & $0,18^{\mathrm{a}} \pm 0,11$ \\
$\mathrm{R}_{3}$ & $0,56 \pm 0,11$ & $0,28 \pm 0,11$ & $3,12^{\mathrm{c}} \pm 0,74$ & $3,00^{\mathrm{b}} \pm 1,91$ & $0,46^{\mathrm{b}} \pm 0,08$ \\
$\mathrm{R}_{4}$ & $0,45 \pm 0,17$ & $0,37 \pm 0,23$ & $3,67^{\mathrm{c}} \pm 1,86$ & $2,72^{\mathrm{ab}} \pm 0,75$ & $0,32^{\mathrm{b}} \pm 0,11$ \\
$\mathrm{R}_{5}$ & $0,60 \pm 0,22$ & $0,45 \pm 0,19$ & $3,33^{\mathrm{c}} \pm 0,93$ & $3,03^{\mathrm{b}} \pm 1,12$ & $0,40^{\mathrm{b}} \pm 0,26$ \\
$\mathrm{R}_{6}$ & $0,50 \pm 0,09$ & $0,33 \pm 0,08$ & $3,09^{\mathrm{c}} \pm 1,98$ & $2,85^{\mathrm{ab}} \pm 1,23$ & $0,35^{\mathrm{b}} \pm 0,09$ \\
\hline
\end{tabular}

Keterangan: R0 (Kontrol Negatif), $\mathrm{R}_{1}(0,5 \% \mathrm{TKBM}+0,5 \% \mathrm{TK}), \mathrm{R}_{2}(1,0 \% \mathrm{TKBM}+1,0 \% \mathrm{TK}), \mathrm{R}_{3}(1,5 \% \mathrm{TKBM}+$ $1,5 \% \mathrm{TK}), \mathrm{R}_{4}(2,0 \% \mathrm{TKBM}+2,0 \% \mathrm{TK}), \mathrm{R}_{5}(2,5 \% \mathrm{TKBM}+2,5 \% \mathrm{TK}), \mathrm{R}_{6}$ (Kontrol Positif). Superskrip yang berbeda menunjukkan perbedaan yang nyata $(\mathrm{P}<0,05)$ 
Tabel 2. Karakteristik Organ Dalam Itik Cihateup Hasil Penelitian

\begin{tabular}{ccccc}
\hline Perlakuan & $\begin{array}{c}\text { Bobot usus } \\
(\%)\end{array}$ & Panjang Usus $(\mathrm{cm})$ & $\begin{array}{c}\text { Ginjal } \\
(\%)\end{array}$ & $\begin{array}{c}\text { Jantung } \\
(\%)\end{array}$ \\
\hline $\mathrm{R}_{0}$ & $2,93 \pm 0,69$ & $166,21^{\mathrm{a}} \pm 18,79$ & $0,57 \pm 0,09$ & $0,96 \pm 0,17$ \\
$\mathrm{R}_{1}$ & $2,76 \pm 1,04$ & $162,45^{\mathrm{a}} \pm 21,09$ & $0,62 \pm 0,18$ & $0,78 \pm 0,38$ \\
$\mathrm{R}_{2}$ & $2,52 \pm 0,38$ & $157,28^{\mathrm{a}} \pm 13,15$ & $0,54 \pm 0,21$ & $0,92 \pm 0,46$ \\
$\mathrm{R}_{3}$ & $3,19 \pm 1,49$ & $185,39^{\mathrm{ab}} \pm 8,34$ & $0,68 \pm 0,34$ & $0,69 \pm 0,15$ \\
$\mathrm{R}_{4}$ & $2,63 \pm 1,22$ & $201,32^{\mathrm{ab}} \pm 32,67$ & $0,51 \pm 0,08$ & $0,87 \pm 0,24$ \\
$\mathrm{R}_{5}$ & $2,81 \pm 0,57$ & $169,48^{\mathrm{a}} \pm 8,90$ & $0,74 \pm 0,52$ & $1,11 \pm 0,51$ \\
$\mathrm{R}_{6}$ & $2,64 \pm 1,34$ & $164,29^{\mathrm{a}} \pm 15,67$ & $0,86 \pm 0,26$ & $1,26 \pm 0,65$ \\
\hline
\end{tabular}

Keterangan: R0 (Kontrol Negatif), $\mathrm{R}_{1}(0,5 \% \mathrm{TKBM}+0,5 \% \mathrm{TK}), \mathrm{R}_{2}(1,0 \% \mathrm{TKBM}+1,0 \% \mathrm{TK}), \mathrm{R}_{3}(1,5 \% \mathrm{TKBM}+$ $1,5 \% \mathrm{TK}), \mathrm{R}_{4}(2,0 \% \mathrm{TKBM}+2,0 \% \mathrm{TK}), \mathrm{R}_{5}(2,5 \% \mathrm{TKBM}+2,5 \% \mathrm{TK}), \mathrm{R}_{6}$ (Kontrol Positif). Superskrip yang berbeda menunjukkan perbedaan yang nyata $(\mathrm{P}<0,05)$

\section{Hati}

Data statistika pada Tabel 1 menunjukkan bahwa perlakuan pakan berpengaruh nyata terhadap persentase bobot hati itik Cihateup. Rataan persentase bobot hati ayam broiler hasil penelitian yaitu berkisar antara 1,88 - 3,67\% dari bobot potong. Hasil ini masih dalam kisaran normal $(1,70-2,80 \%$ dari bobot potong) (Putnam, 1991; Siregar, 2011) meskipun perlakuan R3-R6 memiliki nilai yang lebih tinggi. Sinurat (2002) menyatakan bahwa peningkatan berat hati disebabkan oleh penyakit atau racun yang terbawa bersama makanan. Dengan meningkatnya konsumsi zat beracun maka hati bekerja lebih ekstra untuk menigkatkan produksi dan sekresi empedu guna menetralisir racun tersebut, sebagai konsekuensinya ukuran hati menjadi meningkat.

Bobot hati unggas dipengaruhi oleh beberapa factor yaitu ukuran tubuh, spesies dan jenis kelamin. Selain itu, bobot hati juga dipengaruhi oleh bakteri patogen yang biasanya mengakibatkan pembengkakan hati (Sturkie, 1976; Simamora, 2011). Xanton dan kurkumin yang terkandung pada kulit buah manggis dan kunyit memiliki senyawa antosianin dan tanin yang membantu kinerja hati dalam detoksifikasi racun dengan menghambat dan membunuh bakteri penghasil racun di saluran pencernaan, sehingga darah yang membawa nutrien yang mengalir dari saluran pencernaan melewati hati sudah tidak mengandung racun (Darmawan, 2008; Faishal et al., 2013). Perlakuan pakan kontrol negative memiliki persentase bobot hati yang lebih rendah dibandingkan perlakuan lainnya. Hal ini diduga kandungan pakan itik pada perlakuan R0 memiliki tingkat toksisitas yang jauh lebih rendah dibandingkan perlakuan pakan yang mengandung kombinasi bahan herbal dan kontrol positif. Hal ini dikarenakan hati berperan dalam metabolisme lemak, protein, karbohidrat, zat besi, detoksifikasi racun yang masuk ke dalam tubuh unggas, pembentukan sel darah merah, metabolisme dan penyimpanan vitamin (Ressang, 1984; Aqsa et al., 2016). Kelainan fungsi hati secara fisik biasanya ditandai dengan adanya perubahan warna hati, pembengkakan dan pengecilan pada salah satu lobi (Subronto dan Tjahajati, 2004; Simamora, 2011)

\section{Gizzard}

Hasil penelitian sebagaimana tersaji pada Tabel 1 menunjukkan bahwa perlakuan pakan berpengaruh nyata $(\mathrm{P}<0,05)$ terhadap persentase bobot gizzard. Rataan presentase bobot gizzard tiap perlakuan berturut-turut adalah sebagai berikut 2,18, 1,90, 2,56, 3,00, $2,72,3,03$ dan 2,85\%. Hasil penelitian ini melebihi kandungan persentase gizzard unggas yang normal yaitu 1,6 - 2,3\% dari bobot potong (Sturkie, 2000; Simamora, 2011). Hasil penelitian ini menunjukkan bahwa perlakuan pakan mempengaruhi terhadap fungsi dan perkembangan gizzard itik. Hal ini disebabkan oleh kandungan serat yang dimiliki tepung kulit buah manggis dan tepung kunyit masih tinggi sehingga membuat otot rempela lebih aktif bekerja dan lama kelamaan menjadi menebal. Weiss dan Scott (1979) dalam Rosyani (2013) juga menyatakan bahwa serat 
yang tinggi dalam pakan akan memperbesar ukuran gizzard karena organ tersebut dipacu untuk lebih banyak bekerja secara fisiologis dalam memproses pencernaan serat, baik secara mekanik maupun enzimatis. Hal ini mengakibatkan beban gizzard menjadi lebih besar untuk memperkecil ukuran partikel ransum secara fisik sehingga urat daging gizzard tersebut akan lebih tebal yang berdampak pada membesarnya ukuran gizzard meskipun hal tersebut tidak mempengaruhi fungsi fisiologis dari gizzard.

Gizzard dikenal sebagai muscular stomach (perut otot) atau empedal yang fungsi utamanya bertugas untuk melumatkan pakan dan mencampurnya dengan air menjadi pasta yang dinamakan chymne. Ukuran dan kekuatan gizzard ini dipengaruhi oleh kebiasaan makan unggas. Itik yang dipelihara secara ekstensif seperti penelitian ini akan menyebabkan gizzardnya lebih kuat dari pada itik yang dipelihara secara intensif (Yuwanta, 2004). Selanjutnya, menurut Rosyani (2013) ukuran gizzard dipengaruhi oleh jenis makanan unggas dan tingkat konsumsi ransum karena konsumsi ransum yang tinggi dapat mengakibatkan penebalan pada urat daging gizzard sehingga ukuran gizzard semakin membesar (Rosyani, 2013). Perlakuan pakan yang mengandung kombinasi TKBM dan TK pada level 2,5\% memiliki persentase bobot gizzard yang lebih tinggi dikarenakan pengaruh xanton dan kurkumin pada dosis tinggi yang mampu meningkatkan nafsu makan ternak. Hal ini dikuatkan oleh Akoso (1998) dalam Faishal et al. (2013) bahwa peningkatan konsumsi ransum juga dapat mengakibatkan urat daging gizzard akan lebih tebal sehingga memperbesar ukuran gizzard.

\section{Limfa}

Hasil penelitian sebagaimana tersaji pada Tabel 1. Menunjukkan bahwa perlakuan pakan berpengaruh secara nyata $(\mathrm{P}<0,05)$ terhadap persentase limfa itik Cihateup. Hasil penelitian persentase bobot limfa secara berturut-turut yaitu $0,22,0,22,0,18,0,46,0,32,0,40$ dan $0,35 \%$. Hasil ini masih dalam kisaran kisaran normal dan sesuai dengan penelitian Nurjanah (2007) yang melaporkan bahwa persentase berat limfa pada ayam kampung yang diberi bahan herbal tepung bawang putih sebesar 0,26 - 0,38\% dari bobot hidup. Hal ini menunjukkan bahwa penambahan TKBM dan TK pada ransum itik Cihateup memiliki pengaruh yang baik dalam memelihara kesehatan dan kinerja organ limfa. Hal ini dikarenakan TKBM dan TK mengandung senyawa bioaktif yaitu xanton dan kurkumin yang mampu membantu organ limpa dalam menjalankan fungsinya. Limpa merupakan salah satu organ yang berperan dalam sirkulasi darah yaitu sebagai daerah penampung darah (Frandson, 1992; Aqsa et al., 2016).

Ressang (1984) dalam Aqsa et al. (2016) menyatakan bahwa fungsi limpa, selain untuk menyimpan darah, bersama hati dan sumsum tulang belakang berperan dalam menghilangkan eritrosit-eritrosit tua, ikut serta dalam metabolisme nitrogen terutama dalam pembentukan asam urat dan membentuk limfosit yang berhubungan dengan pembentukan antibodi. Perlakuan TKBM dan TK pada level rendah (R1 dan R2) menunjukkan nilai persentase bobot limfa yang lebih rendah dibandingkan perlakuan lainnya. Perlakuan pakan yang mengandung TKBM dan TK pada dosis rendah mengandung senyawa bioaktif xanton dan kurkumin yang optimal dalam mengendalikan fungsi system limfatik dalam peredaran darah. Hal ini dikarenakan banyaknya darah yang mengalir dalam tubuh ternak mempengaruhi ukuran dan berat limfa (Frandson, 1992; Aqsa et al., 2016). Jika limpa membesar (splenomegali), kemampuannya untuk menangkap dan menyimpan sel-sel darah akan meningkat. Splenomegali dapat menyebabkan berkurangnya jumlah sel darah merah, sel darah putih dan trombosit dalam sirkulasi. Jika limpa yang membesar menangkap sejumlah besar sel darah yang abnormal, sel-sel ini akan menyumbat limpa dan mengganggu fungsinya. Hal ini diduga karena darah yang dari jantung terlalu sedikit, sehingga mengakibatkan penurunan berat limpa, sesuai dengan kerja limpa sebagai penampung darah dari jantung (Aqsa et al., 2016)

\section{Persentase Bobot Usus Halus}

Data statistik pada Tabel 2. Menunjukkan bahwa perlakuan pakan berpengaruh nyata 
terhadap persentase bobot usus halus. Rataan persentase bobot usus halus sebesar 2,52 $3,19 \%$ dari bobot potong. Hasil penelitian menunjukkan bahwa persentase bobot usus halus hasil penelitian masih dalam batas normal dan sesuai dengan penelitian lainnya yaitu 2,31-2,49\% (Elfiandra, 2007), 2,24\% (Kusnandar, 2004), 2,43-3,05\% (Tambunan, 2007) dan 2,84\% (Nuraini, 2010) dari bobot potong. Perkembangan usus halus unggas sangat dipengaruhi oleh kandungan serat kasar dalam ransum yang dikonsumsi oleh ayam broiler. Kandungan serat kasar pada pakan yang dikonsumsi itik sama antar pelakuan sehingga rataan persentase bobot usus halus tersebut tidak berbeda nyata secara statistik. Serat kasar merupakan salah satu zat makanan penting dalam ransum unggas, karena berfungsi merangsang gerak peristaltik saluran pencernaan sehingga proses pencernaan zat-zat makanan berjalan dengan baik.

Sementara ini jumlah dan aktivitas bakteri selulolitik belum diketahui kemampuannya melakukan pencernaan secara fermentatif seperti halnya pada ternak monogastrik yang memiliki anatomi sekum berukuran besar. Kadar serat kasar di dalam ransum unggas yang baik (rasional) sebaiknya tidak boleh melampaui $4,0 \%$ fase starter dan 4,5\% untuk fase finisher (Lubis, 1963). Perlakuan pakan yang mengandung TKBM dan TK memiliki persentase bobot usus lebih tinggi dibandingkan perlakuan kontrol. Hal ini dikarenakan kandungan serat pada TKBM dan TK masih tinggi sehingga berkontribusi meningkatkan kandungan serat pada pakan perlakuan. Hal ini diduga oleh adanya penambahan vili usus dalam mencerna antinutrisi pada pemberian herbal sehingga bobot usus menjadi meningkat. Komponen saponin dan tanin yang terdapat pada TKBM dan TK memberikan kontribusi positif terhadap peningkatan persentase bobot usus halus. Hal ini sesuai dengan laporan Rofiq (2003) bahwa kecernaan bahan pakan dipengaruhi oleh faktor lain pada pakan seperti antinutrisi yang mempengaruhi pertumbuhan struktur vili. Hal ini dapat diduga karena xanton dan kurkumin yang dikandung oleh herbal tersebut telah dapat bekerja efektif dalam mencegah infeksi cacing yang terdapat dalam saluran pencernaan unggas (Simamora, 2011).

\section{Panjang Usus halus}

Hasil penelitian pada Tabel 2. menunjukkan bahwa perlakuan pakan berpengaruh nyata terhadap panjang usus halus. Rataan panjang usus halus masing-masing perlakuan secara berturut-turut yaitu 166,21, 162,45, 157,28, 185,39, 201,32, 169,48 dan 164,29 cm. Hasil ini menunjukkan bahwa panjang usus halus hasil penelitian lebih panjang dibandingkan dengan penelitian (Suprijatna et al., 2008; Warni, 2018) yang hanya mencapai $150 \mathrm{~cm}$. Panjang usus tertinggi terjadi pada perlakuan TKBM dan TK yang dapat disebabkan oleh penambahan serat ke dalam ransum sehingga menimbulkan perubahan bobot dan panjang usus, dimana panjang usus dapat meningkatkan penyerapan nutrient di dalam usus. Selanjutnya Amrullah (2003) dalam Siregar (2011) melaporkan bahwa perubahan panjang usus diikuti dengan jumlah villi usus dan kemampuan sekresi akan meningkatkan kecernaan dan masuknya zat-zat makanan kedalam tubuh dengan konsumsi tetap. Peningkatan kadar serat kasar dalam ransum cenderung akan memperpanjang usus dimana semakin tinggi serat kasar dalam ransum maka semakin lambat laju pencernaan dan penyerapan zat makanan.

Luas permukaan usus akan meningkat seiring dengan bertambahnya jumlah vili usus yang berfungsi untuk penyerapan zat- zat makanan (Frandson, 1992; Aqsa et al., 2016). Kandungan serat kasar yang tinggi pada perlakuan pakan yang ditambahkan suplementasi TKBM dan TK (R1-R5) diduga mengakibatkan laju digesta menjadi lambat karena serat kasar yang tinggi pada pakan memerlukan pencernaan pakan lebih intensif. Laju digesta yang lambat memungkinkan enzim menghidrolisis zat makanan lebih lama sehingga penyerapan zat-zat makanan akan efektif dan kecernaan pakan akan meningkat. Meningkatnya kecernaan dapat diakibatkan oleh peningkatan kapasitas organ pencernaan (Ade, 2002). Dengan demikian, semakin tinggi serat kasar maka akan semakin panjang usus dan persentase bobot usus seiring dengan panjang relative usus. Pemanfaatan serat kasar 
dalam pencernaan memerlukan proses fermentasi sedangkan pada unggas proses itu terbatas sehingga bahan pakan yang mengandung serat kasar tinggi pada umumnya akan sulit untuk dimanfaatkan (Tambunan, 2007).

\section{Ginjal}

Data hasil penelitian pada Tabel 2. menunjukkan bahwa perlakuan pakan berpengaruh secara tidak nyata $(\mathrm{P}<0,05)$ terhadap persentase berat ginjal. Rataan persentase berat ginjal hasil penelitian ini adalah berkisar antara 0,51 - 0,86\%. Hal ini masih dalam kisaran wajar dan sesuai dengan penelitian Dwipayanti (2008) bahwa kisaran persentase berat ginjal ayam kampung yang berumur 12 minggu dengan pemberian tepung daun jarak 2-16\% sebesar 0,63\%-0,83\% dari bobot hidup. Hasil ini menunjukkan bahwa penambahan kombinasi TKBM dan TK dalam ransum tidak mempengaruhi kinerja fisiologis ginjal unggas. Ginjal adalah organ yang menyaring plasma dan unsur-unsur plasma dari darah, dan kemudian secara selektif menyerap kembali air dan unsur-unsur berguna yang kembali dari filtrat, yang akhirnya mengeluarkan kelebihan dan produk buangan plasma. Faktor-faktor utama yang mempengaruhi kerja ginjal adalah komposisi darah, tekanan darah arterial, hormon dan sistem saraf otonom (Frandson, 1992; Aqsa et al., 2016). Ressang (1984) dalam Aqsa et al. (2016) menyatakan bahwa fungsi ginjal adalah mempertahankan susunan darah dengan menggunakan zatzat seperti air yang berlebihan, ampasampas metabolisme, garam-garam anorganik dan bahan-bahan asing yang terlarut dalam darah seperti pigmen darah atau pigmen-pigmen yang terbentuk dalam darah. Perlakuan pakan kontrol positif (R6) memiliki persentase berat ginjal yang paling tinggi dikarenakan ginjal bekerja lebih ekstra dalam menyeimbangkan regulasi proses metabolism antibiotic sintetis di dalam tubuh yang jauh lebih berat dibandingkan antibiotic alami.

\section{Jantung}

Data hasil penelitian pada Tabel 2 . Menunjukkan bahwa perlakuan pakan berpengaruh secara signifikan $(\mathrm{P}<0,05)$ terhadap persentase berat jantung. Rataan persentase berat jantung hasil penelitian ini adalah berkisar antara $0,78-1,26 \%$. Hal ini masih dalam kisaran wajar dan sesuai dengan penelitian sebelumnya yang melaporkan bahwa persentase berat jantung unggas berkisar antara 0,5 - 1,42\% dari bobot hidup (Nickle, 1990; Aqsa et al., 2016). Hasil ini menunjukkan bahwa penambahan kombinasi tepung kulit buah manggis dan tepung kunyit dalam ransum mempengaruhi struktur dan bobot organ jantung serta berpengaruh terhadap kinerja fisiologis jantung unggas. Dimana jantung pada unggas berfungsi untuk mendistribusikan darah ke dalam paru-paru untuk menggantikan oksigen dan karbondioksida dalam menyokong proses metabolisme tubuh.

Pada penelitian ini suplementasi bahan herbal (TKBM dan TK) dalam ransum itik memiliki persentase berat jantung yang berbeda dan bahkan relatif lebih rendah dibandingkan kontrol. Perbedaan ini diduga karena adanya perbedaan pertumbuhan dan aktivitas itik pada masing-masing perlakuan. Ressang (1984) dalam Aqsa et al. (2016) melaporkan bahwa ukuran jantung sangat dipengaruhi oleh jenis ternak, umur, ukuran tubuh dan aktivitas ternak. Hal ini sesuai dengan penelitian Crawley et al. (1980) dalam Simamora (2011) yang melaporkan bahwa semakin bertambah umur ternak, maka berat jantung akan semakin meningkat pula. Hal ini menunjukkan bahwa penggunaan herbal tidak menimbulkan pembesaran ukuran jantung akibat adanya akumulasi racun pada jantung (North and Bell, 1990 dalam Widianingsih 2008). Proses pembesaran ukuran jantung ini biasanya disebabkan oleh adanya penambahan jaringan otot jantung (Ressang, 1984; Aqsa et al., 2016). Selanjutnya Frandson (1992) dalam Aqsa et al. (2016) menyatakan bahwa jantung sangat sensitif terhadap racun dan zat antinutrisi yang terkandung pada ransum, dimana pembesaran jantung dapat terjadi karena adanya akumulasi racun pada otot jantung. Perlakuan pakan R6 yang mengandung antibiotic sintetis memiliki 
persentase bobot jantung yang lebih tinggi dibandingkan perlakuan lainnya disebabkan karena toksisitas antibiotic sintetis jauh lebih tinggi dan beresiko dibandingkan antibiotic alami yang terkandung pada TKBM dan TK.

\section{KESIMPULAN DAN IMPLIKASI}

\section{Kesimpulan}

Kombinasi tepung kulit buah manggis dan tepung kunyit memberikan pengaruh yang nyata $(\mathrm{P}<0,05)$ terhadap persentase organ dalam yaitu hati, gizzard, limfa dan panjang usus. Adapun pada perlakuan proventrikulus, pancreas, bobot usus dan ginjal, perlakuan pakan tidak memberikan pengaruh yang signifikan $(\mathrm{P}>0,05)$.

\section{Implikasi}

Perlakuan pakan R3 yang mengandung kombinasi TKBM dan TK sebesar 1,5\% direkomendasikan sebagai feed additive untuk memperbaiki persentase organ dalam unggas.

\section{DAFTAR PUSTAKA}

Ade, A. 2002. Presentase Berat Karkas dan Organ Dalam Ayam Broiler yang Diberi Tepung Daun Talas (Coiocasia esculenta L.) Schott) Dalam Ransumnya. Skripsi. Fakultas Peternakan Institut Pertanian Bogor. Bogor.

Ahmadi, F. 2010. Effect of turmeric (Curcuma longa) powder on performance, oxidative stress state and some of blood parameters in broiler fed on diets containing aflatoxin B1. Global Veterinaria. 5: 312-317.

Akoso, B.T. 1998. Kesehatan Unggas. Kanisius. Yogyakarta.

Akram, M. S. Uddin, A. Afzal, K. Usmanghani, A. Hannan, E. Muhiuddin, and M. Asif. 2010. Curcuma longa and curcumine : a review article. Romanian Journal of Biology - Plant Biology. 55 (2) : 65 - 70.

Amrullah, I.K. 2003. Nutrisi Ayam Broiler. Cetakan ke-2. Lembaga Satu Gunung Budi, Bogor.

Aqsa, A.D., Kiramang, K. and Hidayat, M.N. 2016. Profil organ dalam ayam pedaging (broiler) yang diberi tepung daun sirih (piper betle linn) sebagai imbuhan pakan. Jurnal Ilmu dan Industri Perternakan. 3(1) : 148-159.
Auza, Astuti F. 2010. Efektifitas Pemberian serbuk Kunyit, Bawang Putih dan Mineral Zink Terhadap Kadar Kolestrol Darah dan Bobot Organ Dalam pada Broiler. Tesis. Program Studi Sistem-sistem Pertanian Konsentrasi Peternakan Program Pascasarjana Universitas Hasanuddin, Makassar.

Awad, W. A., K. Ghareeb, S. Abdel-Raheem, \& J. Bohm. 2009. Effects of dietary inclusion of probiotic and synbiotic on growth performance, organ weight, and intestinal histomorphology of broiler chickens. Poultry Science. 88: 49-55.

Ayoub, M., A. El-far, N. Taha, M. Karshom, A. Mandour, A. Abdul-hamied, and M.S. Elneweshi. 2011. The biochemical protective role of some herb against aflatoxicosis in duckling : I. Turmeric. Lucrări Ştiinţifice. 50: $150-159$.

Crawley, S.W., D.R.Sloan \& K.K. Hale. 1980. Yield and composition of edible and inedible byproduct of Broiler processed at 6,7 and 8 weeks of age. Poultry Science. 59:2243-2246

Darmawan, A. 2008. Pengaruh Pemberian Tepung Daun Sembung (Blumea balsemifera) Dalam Ransum Terhadap Presentase Berat Karkas, Organ Dalam dan Lemak Abdomen Broiler. Skripsi. Fakultas Peternakan Institut Pertanian Bogor.

Djunaidi, I. H., T. Yuwanta, Supadmo \& M. Nurcahyanto. 2009. Performa dan bobot organ pencernaan ayam broiler yang diberi pakan limbah udang hasil fermentasi Bacillus sp. Media Peternakan. 32(3): 212-218.

Dwipayanti, Y. 2008. Profil organ dalam serta histopatologi usus dan hati ayam kampung terinfeksi cacing Ascaridia galli yang diberi tepung daun jarak (Jathropa curcas.L). Skripsi. Fakultas Peternakan. Institut Pertanian Bogor, Bogor.

Elfiandra. 2007. Pemberian warna lampu penerangan yang berbeda terhadap organ dalam ayam broiler. Skripsi. Fakultas Peternakan. Institut Pertanian Bogor, Bogor.

Erhan M.K., Bölükbaşı Ş.C., Ürüşan H. 2012. Biological activities of pennyroyal (Mentha pulegium L.) in broilers. Livestock Science. 146(2):189-192.

Faishal, I.J., Djunaidi, I.H. and Sudjarwo, E. 2013. Effect of addition mangosteen peel powder (Garcinia mangostana L.) to feed on carcass and internal organs mojosari drake. Jurnal Brawijaya. 5 (1): 1-10. 
Frandson, R.D. 1992. Anatomi dan Fisiologi Ternak. Edisi ke-4. Gadjah Mada University Press. Yogyakarta.

Kusmayadi, A., Bachtiar, K.R. and Prayitno, C.H. 2019a. The effects of mangosteen peel (Garcinia mangostana L.) and Turmeric (Curcuma domestica Val) flour dietary supplementation on the growth performance, lipid profile, and abdominal fat content in Cihateup ducks. Veterinary World. 12(3): 402-408.

Kusmayadi, A., Adriani, L., Abun, A., Muchtaridi, M. and Tanuwiria, U.H. 2019b. Antioxidant activity of mangosteen peel (Garcinia mangostana L.) extracted using different solvents at the different times. Drug Invention Today. 11(1):44-48.

Kusnandar, N. 2004. Kandungan Kolesterol Daging, Lemak Abdominal, dan Presentase Organ Dalam Ayam Broiler yang Diberi Minum Teh Fermentasi Kombucha pada Waktu yang Berbeda. Skripsi.Program Studi Nutrisi dan Makanan Ternak. Institut Pertanian Bogor. Bogor.

Lehninger, A. L. 1982. Dasar-Dasar Biokimia. Jilid 3. Terjemahan: M. Thenawijaya. Erlangga, Jakarta.

Lubis, D.A., Ilmu Makanan Ternak. 1963. PT Pembangunan Djakarta. Cetakan ke-2. Jakarta.

Moghadamtousi, S. Z., H. A. Kadir, P. Hassandarvish, H. Tajik, S. Abubakar, and K. Zandi. 2014. A Review on antibacterial, antiviral, and antifungal activity of curcumin. BioMed Research International. 2014: 1-12.

Moongkarndi, P., N. Kosem, S. Kaslungka, 0. Luanratana, N. Pongpan, and N. Neungton. 2004. Antiproliferation, antioxidation and induction of apoptosis by Garcinia mangostana (mangosteen) on SKBR3 human breast cancer cell line. Journal Ethnopharmacology. 90 (1): 161-166.

North, M.O. \& D.D. Bell. 1990. Comercial Chicken Production Manual.4th Edition. Chapman and Hall, New York.

Nuraini. 2010. Performa, persentase karkas, lemak abdominal dan organ dalam ayam broiler yang diberi ransum dengan penambahan prebiotik dan tongkol jagung. Skripsi. Fakultas Peternakan. Institut Pertanian Bogor. Bogor.

Nurjanah, S. 2007. Pengaruh pemberian bawang putih dalam ransum terhadap organ dalam serta histopatologi usus dan hati ayam kampung yang diinfeksi telur Ascaridia galli.
Skripsi. Fakultas Peternakan. Institut Pertanian Bogor. Bogor.

Pilliang, W.G. dan Djojosoebagio S. 2006. Fisiologi Nutrisi Volume I. Institut Pertanian Bogor Press. Bogor.

Putnam, P. A. 1991. Handbook of Animal Science. Academy Press. San Diego.

Rahayu, I., Sudaryani T., Santosa H. 2011. Panduan Lengkap Ayam. Penebar Swadaya. Jakarta.

Ressang. 1984. Patologi Khusus Veteriner. Edisi ke-2. N.V. Percetakan Bali. Denpasar.

Rofiq, M.N. 2003. Pengaruh pakan berbahan baku lokal terhadap performa vili usus ayam broiler. Jurnal Sains dan Teknologi Indonesia 5(5):190-194.

Rosyani, S. 2013. Pemberian Pakan Konsentrat Mengandung Tepung Inti Sawit yang Ditambahkan Pollard atau Dedak dan Pengaruhnya terhadap Persentase Organ Dalam Ayam Broiler. Skripsi. Institut Pertanian Bogor. Bogor.

Simamora, N. 2011. Performa produksi dan karakteristik organ dalam ayam kampung umur 12-16 minggu yang diinfeksi cacing Ascaridia galli dan disuplementasi ekstrak daun jarak pagar (Jatropha curcas Linn). Skripsi. Fakultas Peternakan. Institut Pertanian Bogor. Bogor.

Sinurat A.P., T. Purwadaria, M.H. Togatorop, T. P asaribu, I.A.K. Bintang, S. Sitompul and J. Rosi da. 2002. Responses of broilers to Aloe vera b ioactives as feed additive: The effect of differ ent forms and levels of bioactives on perform ances of broilers. JITV. 7(2): 69-75.

Siregar, D.Z. 2011. Persentase karkas dan pertumbuhan organ dalam ayam broiler pada frekuensi dan waktu pemberian pakan yang berbeda. Skripsi. Fakultas Peternakan. Institut Pertanian Bogor. Bogor.

Sturkie, P.D. 1976. Avian Physiology. The 3rd Edition. Springer Verlag. New York.

Sturkie, P.D. 2000. Avian Physiology. 4th Edition. Spinger-Verlag, New York.

Subronto \& I. Tjahajati. 2004. Ilmu Penyakit Ternak II. Gajah Mada University Press. Yogyakarta.

Suprijatna, E., U. Atmomarsono, dan R. Kartasudjana. 2008. Ilmu Dasar Ternak Unggas. Penebar Swadaya. Jakarta.

Tambunan, I. R. 2007. Pengaruh pemberian tepung kertas koran pada periode grower terhadap persentase karkas, lemak abdominal, organ dalam dan saluran pencernaan ayam broiler. Skripsi. Fakultas Peternakan, Institut Pertanian Bogor. Bogor. 
Warni, I.S. 2018. Pengaruh pemberian air rebusan kunyit (Curcuma domestica) terhadap total mikroba dan escherichia coli serta bobot sekum ayam broiler. Skripsi. Fakultas Peternakan dan Pertanian, Universitas Diponegoro. Semarang.

Weecharangsan, W., Opanasopit, P., Sukma, M., Ngawhirunpat, T., Sotanaphun, U., and Siripong P., 2006, Antioxidative and neuroprotective activities of extracts from the fruit hull of mangosteen (Garcinia mangostana Linn.). Medical Principles and Practice. 15(4):281-287.
Weiss, F.G. and Scott, M.L. (1979) Effects of dietary fiber, fat and total energy upon plasma cholesterol and other parameters in chickens. Journal of Nutrition. 109: 693-701.

Widianingsih, N.M. 2008. Persentase Organ Dalam Broiler yang Diberi Ransum Crumble Berperekat Onggok, Bentonit, Dan Tapioca. Skripsi. Fakultas Peternakan. Institut Pertanian Bogor.

Yuwanta, T. 2004. Dasar Ternak Unggas. Kanisius. Yogyakarta. 
